\title{
Social Media and its impact in Nagaland An analysis on "Mission Pothole" a social network initiative.
}

\author{
Imnasenla \\ Research Scholar, School of Journalism and New Media Studies, IGNOU, India
}

\begin{abstract}
Today the world is called a global village. This is attributed to the rapid growth of civilization and revolution in Information Technology. Nagaland a remote northeastern state in India was very recently unknown to the outside world. But thanks to the Internet and other forms of Information Technology, Nagaland is today a part of the global village. Different forms of media have invaded the lives of the Nagas today. However, the foray of social media into the Naga society has differently impacted their thoughts and actions. Social Media has been criticized for a lot of reasons in many countries, but the purpose of the study is to define positive aspects of a particular social networking blog, whose sole aim is to work for social upliftment. The finding of this study suggests that youths in online communities actively follow campaigns and participate in social movements. Overall, the findings show that through social media networks, youths can mobilize people of different communities and regions for a common cause.
\end{abstract}

Keywords: Social Media, ICTs, Mass Media, Mobilization, Social movements

\section{Introduction}

Nagaland is known to be a remote state in the far Northeastern part of India. Nagaland attained its statehood on $1^{\text {st }}$ of December, 1963, becoming the $16^{\text {th }}$ state of India. It has 1.9 million populations with eleven districts, comprising of 16 tribes and various sub-tribes which have their own languages and dialects.

Even after forty nine years of statehood, a huge digital divide exists between the rural and the urban set up. Information Technology (ICT) has reached this far corner state very recently and is spreading rapidly in the urban areas. However, there is still limited penetration of internet and lack of computer knowledge among the rural populace.

With very little means of communication, Nagas were long deprived of basic internet facilities and infrastructures on ICT. With the venturing of different telecommunication companies and importance given by the state government on information technology, the state is however, witnessing a wave of change amongst the users and their attitudes especially in the urban areas. Nagaland is gradually connecting to the rest of the world virtually.

Ever since its inception, ICT in Nagaland has yielded enormous benefits for the people, especially the youths. The outcome of which is the formation of social networks in different social media forums. Social networks are currently creating a huge wave of social change in the state.

Today, social media is reinventing the way young people are thinking and bringing about a social change in the society. Inspite of the digital divide among the rural and the urban set up; Naga youths are keen on taking the help of Social Media to awaken policy makers on issues such as corruption, electricity, bad road conditions, water supply etc. Such social networks are also beginning to have a bigger role in community building.

Although the precise contribution of the internet is hard to establish, the internet has given civil society new tools to support their claims (Van Laer et al. 2010). Social movements can be defined as 'networks of informal interaction between a plurality of individuals, groups and/or organizations, engaged in a political or cultural conflict on the basis of a shared collective identity' (Diani 1992, p. 13).

This study investigates wall post contents of the Naga Blog on the social networking site Facebook. This article will study on the impacts of the social media and how it is shaping the collective action repertoire of social movements pursuing social change. To speak of a social movement generally four elements should be present: (1) a network of organizations, (2) on the basis of a shared collective identity, (3) mobilizing people to join, mostly unconventional1 actions (4) to obtain social or political goals (Diani and Eyerman 1992). In this case we would broaden the concept of social movement to that of a 'transnational social movement organization' (TSMO) (Smith et al. 1997). This concept refers to a network of organizations that is not bound by state barriers and that connects people and places 'that were formerly seen as distant or separate' (O'Brien et al. 2000: 13). Though a very small state, Nagaland fails to integrate its different districts due to poor communication facilities. 
Social Media and its impact in Nagaland An analysis on "Mission Pothole" a social network

\subsection{Contextualization of the concept}

Social media has made a profound impact on the 21 st century social interaction. Today, logging into Social media has become a necessary societal norm. Virtual communities are gaining popularity all over the world. While certain communities and forums have invited criticisms for invoking hatred and divisions, many social networks are coming together for common interest to uplift the social economic status of their societies. People are informed, can make suggestions or complaints, and can vote on local issues using the Internet. The article is an analysis of a particular social networking website. Three dimensions of social movements constitute the theoretical framework of the study. They include the contribution of the Internet to the different elements or conditions that establish movement formation, actual mobilization of participants, and a network of different organizations.

\subsection{Objectives}

The decision to confine the study to an analysis of a particular social network has led to more emphasis on the role of new ICTs for social movements.

Studying networking sites are an interesting starting point for several reasons.

(I) First of all they contain lots of information on the actual organization(s). How are they organized? What do they stand for? What issues do they stress?

(2) The study wanted to examine to what extent these sites are also used as a means for mobilization? How detailed is the information on these actions? Is the Internet used as a means for action on its own?

(3) The study also wanted to know whether the social movement could move beyond their specific areas and did the movement impact the authorities and the general public.

\section{The Naga Blog (TNB)}

Lately, Internet users which comprises mainly the youths, have created different forums and groups according to their social beliefs and interest. One organization that has used social media to encourage community action is The Naga Blog (TNB). TNB is an initiative by young Naga youths to create a platform for the youths and common man to voice their opinions and discuss a wide range of issues focusing on social and political subjects in the region. TNB has more than 17,000 members. The creators of the blog defend themselves to be non-political and not affiliated to any organization and political party, but are devoted for people's movement. The Naga Blog has initiated numerous campaigns in the past such as the Sikkim earthquake relief, Mon fire tragedy relief operations and renovation of Dimapur Civil Hospital (Kikon,Y 2012 ). The recent campaign carried out by TNB is the "Mission Pothole" which has gained popularity amongst the youths and has continued to gather momentum across the districts of Nagaland.

\subsection{Mobilization of youths through Facebook}

Social movement organizations wanting to mobilize for a mass street demonstration make extensive use of the internet to enhance coordination and mobilization efforts (Van Laer 2010). This concerns mainly the distribution of information, both about the reasons and goals of the action, as more strategic information concerning the action itself (Jeroen Van Laer et al.)

The internet helps organizations in providing detailed information on time, place and gives detailed guide for activists to 'inform people on how to organize, on their rights and how to protect take the message across to all sections of the society, as was the case on Mission Pothole organized by the social networking site Facebook in the name of The Naga Blog.

The Naga Blog uses existing social network such as the Facebook to help change people's attitude towards social change. "Mission Pothole" was one example on how social media can be used to inspire people to get involved in community life. The campaign was mobilized through the popular social networking site Facebook. The young bloggers embarked on a mission to draw the attention of the authorities on the deplorable conditions of roads in the State. The movement first started in Dimapur on $28^{\text {th }}$ of July 2012 by the members of the blog. The bloggers began their movement by walking through the heart of the city and planted rice saplings and fishing at every pothole they came across. Administrators of the blog claim that the campaign started after a long discussion and analysis of the condition of roads in Nagaland. The main objective of the mission was to grab the attention of the media and the authorities whose prime responsibility is to build and maintain good roads (TNB).

The wave started to spread across the state through the media, internet, mobile phones and word of mouth. Since many districts have poor internet facilities and power failures, members of TNB mobilized other members reachable through Facebook and then they mobilized the members deprived of internet facilities through mobile phones and word of mouth. Places like Mon and Tuensang (bordering Myanmar), which are the remotest districts in Nagaland also joined the campaign. 
Social Media and its impact in Nagaland An analysis on "Mission Pothole" a social network One blogger from Mon district RL Pavei Kinamai wrote that "awareness is the highest peak of growth, lets join hands and create a bridge of change. We must, we should and we can".

Su Lot a member of the blog wrote, "It is a creative way of protesting and making a point with fun and humour and with drama and street play style. Doing differently from the old school type, where we hold placards, shouts slogan and protest, but this is more friendly, fun and anyone can join in even children".

TNB member Vikeduo Linyu wrote that "the greatest show on Earth will happen in London at 1:30 am on $28^{\text {th }}$ July 2012, but the greatest show for us Dimapurians is $28^{\text {th }}$ July 20122.00 P.M. Time will tell the world we are not just bystanders but citizens who wants our rights".

Blogger and renowned music artiste of Nagaland, Alo Wanth, commented on the blog that "the vision behind the mission is beyond any particular political party and it was done not to point fingers at anyone but to raise their voice for truth and for the people of Dimapur and Nagaland".

The mission began to grow bigger with every chapter from Zunheboto, Kohima and Mokokchung, Wokha, Phek, Tseminyu, Tuensang, Peren and Mon. In Peren district bloggers coordinated and organized the mission through Facebook. In the blog one blogger from Peren urged its members to support and co-operate in the mission to make it a success in their district too. The campaign was mobilized by TNB and also supported by the Town Youth organization. Mobilizations of members started in Peren on $12^{\text {th }}$ August 2012 and set the target for their campaign on $18^{\text {th }}$ August 2012.

1.1Figure showing number of participating districts, date of mobilizing members/youths and the date of the campaign "Mission Pothole"

\begin{tabular}{|l|l|c|l|}
\hline No & Districts & Date of mobilizing & Date of Campaign \\
\hline 1 & Dimapur & -------- & $28^{\text {th }}$ July 2012 \\
\hline 2 & Zunheboto & $27^{\text {th }}$ July 2012 & $30^{\text {th }}$ July 2012 \\
\hline 3 & Kohima & $27^{\text {th }}$ July 2012 & $31^{\text {st }}$ July 2012 \\
\hline 4 & Mokokchung & $29^{\text {th }}$ July 2012 & $3^{\text {rd }}$ August 2012 \\
\hline 5 & Wokha & $29^{\text {th }}$ July 2012 & $4^{\text {th }}$ August 2012 \\
\hline 6 & Phek & ------------- & $7^{\text {th }}$ August 2012 \\
\hline 7 & Tuensang & $1^{\text {st }}$ August 2012 & $8^{\text {th }}$ August 2012 \\
\hline 8 & Tseminyu & $31^{\text {st }}$ August 2012 & $9^{\text {th }}$ August 2012 \\
\hline 9 & Peren & $12^{\text {th }}$ August 2012 & $18^{\text {th }}$ August 2012 \\
\hline 10 & Mon & $30^{\text {th }}$ July 2012 & $18^{\text {th }}$ August 2012 \\
\hline
\end{tabular}

The fig. has been prepared using the wall content on Naga Blog. As per the wall content on Naga Blog (Facebook), the campaign began on $28^{\text {th }}$ of July 2012 from Dimapur and culminated in Mon on $18^{\text {th }}$ August 2012. Fig 1.1 shows that the campaign gathered momentum right after the mission in Dimapur. The members in each district were supported by TNB in matters of organizing placards, banners, suggestions etc. The wall contents showed that in each place, more than hundred members, including parents, elders and well wishers participated in the Mission pothole. The members of TNB could also make an impact on non-members of the blog. Many youth organizations joined the campaign in support of the campaign and expressed their resentment on the pathetic road conditions of their respective colony roads.

\section{Role Of Media In Mission Pothole}

The Media in Nagaland was also awakened by the sudden popularity of Mission Pothole. Both print and electronic media started taking interest in the mission. Nagaland which otherwise gets very little mention in the National dailies, the Mission pothole got to be recognized and was published in some national as well as regional dailies. Some renowned bloggers also wrote on the Mission pothole in Nagaland and compared it with the roads in Delhi and other metropolitan cities in India.

The Telegraph a renowned national daily, reported that a unique mission has begun in Nagaland in remonstration against the state government's apathy towards the lifeline of economic growth in every society ' roads. The paper further reported that Nagaland ' the land of festivals", coined by the current state government, has turned into a "land of potholes" for the Naga youths and students (The Telegraph 6 Aug, 2012).

Eastern Mirror reported that the movement has been drawing huge response from the public with people from all walks of life joining the youth and cheering them on in their mission. 
Social Media and its impact in Nagaland An analysis on "Mission Pothole" a social network

In an article by Yan Kikon the founder of The Naga Blog (Nagaland Post), he observed that the protest across the state was not met with violence but smiles and the Government also responded positively.

A blogger from Delhi wrote on her blog that she is contemplating of copying the most brilliant protest that is taking place in Nagaland and do the same campaign in Delhi. Christine wrote that people are protesting by symbolically planting rice in the holes, fishing in them, swimming in them - all manner of creative out of the box thinking (Christine 2012).

Assam Tribune a regional daily reported that the movement has gathered momentum and is spreading across the districts in Nagaland.

Realizing the sudden impact of Mission Pothole in the state, a TV talk show was organized by Doordarshan Northeast's in their programme Trends of Nagaland which is broadcast every Saturday. Panelist from the state government, contractor, members of the blog and students were invited to discuss on the most happening issue, the Mission Pothole. Taking part in the discussion, Commissioner and Secretary (Works \& Housing) of Nagaland, Mr. Temjen Toy said the government gives highest priority to roads but "somehow major problems do crop up in as far as maintenance is concerned with source of funding being a major issue." Citing several reasons for deteriorating road conditions in the state, he said it hurt him to see young people's displeasure and as the administrative head of the department, he took responsibility for any dereliction of assigned duties on the part of his officers especially in monitoring and evaluation of works assigned to contractors. Responding to a query on the amount received by the department in the current year, Toy informed that it had been allocated with Rs.250 Crores under Plan which ultimately would be utilized for up-gradation and improvement of roads. Also taking part in the discussion, President of Nagaland Contractors and Suppliers' Union, Pele Khezhie said contractors give all out efforts while implementing assigned works, but defended that land instability and lack of civic sense act as deterrents to quality output in civil works. Bloggers representing The Naga Blog, Robert Solo, Theja Vizo and Susan described the concept of initiating the "Mission Pothole" as a good idea to send a message across to the government to address the issue of poor roads.

\section{Results}

After a month of analyzing the social networking site Facebook, the author found that Mission Pothole created a huge impact in the society. The campaign awakened both the authorities and the public at large. The common people were also sensitized on their responsibilities, to be not just mute spectators of corruption and poverty; but rise up to the occasion and make a difference. For long the government authorities have been lackadaisical, but the campaign has shaken them and moved them. Nagaland Post reported that while the youth were on a mission for better roads, the Public Works Department and the Road \& Bridges departments at Zunheboto were busy repairing some parts of the road at Zunheboto town. "Although without any sanction for repair of roads, the R\&B department filled the potholes belonging to the National Highway Authority" (Nagaland Post 2012). In other districts too, potholes were filled and roads were widened by the authorities concerned.

The campaign drew attention from various quarters which included scholars, writers, common people, political parties and different social organizations. They all lauded the efforts of the bloggers and encouraged the movement to be carried out in checking corruption and bringing social change in the society. In an article by Vebeiletuo Kits, he lauded the young bloggers for their commendable campaign and said the campaign is a time texted approach of non-violence which was optimally exploited by Mahatma Gandhi against the colonial power to show the shape of things to come in our society (Kits,V. 2012).

Nagaland State NCP also lauded the bloggers and the youths in general for highlighting the pitiable condition of roads all over the state by enacting mock fishing and paddy planting in the potholed roads. "I am happy that Naga youths are now coming forward and pointing out at the mistakes and non-performance of the state government. It is high time that our youths awake today and do something about the sorry state of affairs in our state since the future belongs to them", the state NCP president Neiba Ndang said. Mission Pothole has empowered youths to go the extra mile and fight for their rights and embark on a mission which they never realized existed. Many Naga youths have now decided be file Right to Information (RTI) query to know about the total amount sanctioned for maintenance of roads in the state. Morung Express reported that some youths representing three colonies in Dimapur are protesting for not receiving any funds for development of roads for the past five years and wanted to know where and how the "funds went missing (Morung Express 2012).

\section{Conclusion}

The article focused on how social media can be an important medium to awaken the minds of the people for any kind of social cause/movement. It also helped in focusing how Information Communication Technologies (ICT) can usher in the development of even the remotest places in the world. ICT has helped in facilitating different forms of information and made it possible to reach more people more easily, in a time-span that was unthinkable for a place like Nagaland before. 
Social Media and its impact in Nagaland An analysis on "Mission Pothole" a social network

The paper analyzed the different missions held in different districts. The movement started from the commercial hub of Nagaland, Dimapur than to Zunheboto, Kohima (the capital of Nagaland) and to the other remote districts within a period of two weeks. The results show a strong case in favour of social media networks which is facilitated by ICT, as it has given social movements new and improved opportunities to engage in social issues. It shows information spreads so rapidly even in a place deprived of internet facilities and how these people yearn to make use of such facilities to bring about social change in their society.

Though digital divide still exist in Nagaland and around the world, it is imperative to note that even in a remote place the presence of ICT can be felt and is creating a huge difference in the lives of the rural people. It also analyzed how social networking sites can be used to mobilize different groups of people living in different places for a common cause or movement.

Though scholars and researchers are of the view that even a wide digital action repertoire will not and probably never will, be able to replace traditional forms of activism and face-to-face communication; this particular social movement in the name of Mission Pothole has in its own way proved that inspite of the many controversies surrounding social networking sites, there is a positive perspective on the use social media. The analysis revealed that youths were long deprived of their freedom to express their angst against mismanagement, corrupt government functionaries, pathetic road conditions and deprivation of basic human needs.

Social networking sites like the Facebook have given the youths a platform where they can come together for a common cause and fight for it. It has been righty noted by Dalton that activists and social movements have now often found straightforward ways to reconnect with ordinary citizens, and especially with youngsters, in the face of apparently ever-increasing public disengagement from formal political institutions and processes (cf. Dalton 2008). One interesting aspect of the study was the overwhelming number of participants and wall post activities by the members of the Naga Blog on the Mission Pothole.

The study also revealed the role of mass media in facilitating the Mission Pothole campaign. The campaign further gained its impetus through the support and coverage by the mass media. Even in places where there was limited internet connections, mobile phones and word of mouth were used to mobilize the youths. It is also very interesting to note that the small campaign carried out in the far corner of state of India, attracted media attention and its coverage.

Though the study concludes that social networking sites can be used to create social change in the society, there are lots of limitations, because the study analyzed only one social networking blog, the Naga Blog in Facebook. Further research is needed to identify how social networking sites mobilize members from different groups for common social movements.

Inspite of its limitations, the study might offer fruitful insights for scholars and researchers to know that social media can also make a positive impact and change the way people think even in the remotest part of the world.

\section{References}

[1] Diani, M. The concept of social movement, Sociological Review, vol. 40,no. 1, 1992 pp. 1-25.

[2] Van Laer,J. \& Peter Van Aelst: Internet and social movement action repertoires, Information, Communication \& Society, 13:8, [3] 20101146-1171

[4] Van Laer, J. Activists "online" and "offline": internet as an information channel for protest demonstrations', Mobilization: An International Journal, vol. 15, no. 3, 2010 pp. 405-421

[5] Diani, M. and Eyerman, R. (eds) Studying Collective Action, London (Sage, 1992).

[6] O'Brien, R., Goetz, A., Scholte, J. and Williams, M. Contesting Global Governance. Multilateral Economic Institutions and Global Social Movements, Cambridge (Cambridge University Press, 2000).

Smith, J., Chatfield, C. and Pagnucco, R. (eds) Transnational Social Movements and Global Politics: Solidarity Beyond the State (New York: Syracuse University Press, 1997).

Land of fests turns into land of potholes (www. telegraphindia.com) 2012 accessed on $7^{\text {th }}$ August 2012.

Mission pothole' spreads across Nagaland

(http://www.assamtribune.com/scripts/detailsnew.asp?id=aug0612/oth06) accessed on 14th August 2012

A spot of fishing in Delhi's flooded pot-holes anyone ?( www.christinepemberton.me/? $\mathrm{p}=14029$ )accessed on $16^{\text {th }}$ August 2012 .

Mission Potholes: 'Better learn swimming than driving' (Morung Express 4thAugust 2012).

Kikon, Y, The Alpha and Omega of mission potholes (Nagaland Post $28^{\text {th }}$ August 2012)

Kits, V, The emergence of Naga Bloggers (Morungexpress Aug 2012).

Ndang lauds Naga Blog youths (Morung Express $8^{\text {th }}$ August 2012). 